Int. J. Morphol.,

28(3):723-728, 2010

\title{
Electron Microscopic Evaluation of the Secretory Mechanisms of Renin from Juxtaglomerular Cells
}

\author{
Evaluación con Microscopía Electrónica de los Mecanismos \\ Secretorios de Renina desde las Células Juxtaglomerulares
}

"Ranan Gulhan Aktas; ** Gulten Karabay; ${ }^{* * *}$ Oguz Taskinalp \& ${ }^{* * * *}$ A. Kemal Kutlu

AKTAS, R. G.; KARABAY, G.; TASKINALP, O. \& KUTLU, A. K. Electron microscopic evaluation of the secretory mechanisms of renin from juxtaglomerular cells. Int. J. Morphol., 28(3):723-728, 2010.

SUMMARY: Although the structure and the functions of juxtaglomerular cells (JG) have been well defined, there is still a controversy about the secretory mechanisms of renin from these cells. It has been assumed that exocytosis is the main secretory mechanism in these cells in many studies, while others suggest that secretion occurs in a quite different way in these cells. There are several studies suggesting that diacrine secretion, which is very difficult to visualize, might be the other mechanism for secretion of renin. This study is an attempt to find the answers of these questions by identifying the fine structural features of the secretory granules in juxtaglomerular cells. Cyclosporin A (CyA) has been used in the current experimental study since it has already been reported that this drug increases the number of JG cells and stimulates secretion of Renin. Twelve female Sprague-Dawley rats had daily intraperitoneal injections of CyA for ten weeks. Tissue specimens from the kidneys of these animals were examined by electron microscopy. Fine structural characteristics of the secretory granules of juxtaglomerular cells have been examined. Considerable amount of granules, which goes to the exocytotic process, have been observed. Additionally, several cells, which their granules had been secreting their contents in a different way, were found. This was interpreted as the secretion type of diacrine secretion. In conclusion, this in vivo study presents morphologic evidences demonstrating that both exocytosis and diacrine secretion might occur in JG cells. We also had a chance to observe secretory granule probably exhibiting "diacrine secretion", which is very difficult to visualize, at electron microscope level for the first time. This report also provides morphologic proof which shows that these two distinct secretory mechanisms might occur simultaneously in the same juxtaglomerular cell.

KEY WORDS: Juxtaglomerular cells; Secretory granules; Microscopy.

\section{INTRODUCTION}

Although there has been much evidence that renin is synthesized in juxtaglomerular cells and then released from these cells, no morphological consensus has been reached about the secretory mechanisms of the secretory granules of these cells. Many studies suggest that exocytosis is the main mechanism of renin release (Berka et al., 1990; Berka et al., 1993; Ogawa et al.; 1995; Rasch et al.; 1998; Persson, 2004; Schweda \& Kurtz, 2004; Friis et al., 2000; 2005). Rasch et al. did a quantitative study and reported that the reduced number of renin granules after acute stimulation is compatible with exocytosis as the dominating mechanism of renin release. In the study by Friis et al. (2002) patch clamp experiments were made on isolated JGCs. They found increases in membrane capacitance which indicated cell surface area increase, and this is an accepted measure of exocytosis at the level of the single cell. In contrast to the above results, Fray et al. (1983) postulated that secretion of renin from secretory granules occurs by a process quite different from exocytosis. Argument for exocytosis in JG cells has continued since Skøtt (1986) observed that renin secretion occured in 'quanta' rather than continuously. Kon et al. (1992) outlined two hypothetical secretory mechanisms in their study. They suggested that one type of renin release might occur through the formation of exocytotic channels that are somewhat different in morphology from those found in other endocrine cells. Specifically, they theorized that the

* Koc University faculty of Medicine, Department of Histology and Embryology, Istanbul, Turkey.

** Baskent University Faculty of Medicine, Department of Histology and Embryology, Ankara, Turkey.

*** Trakya University Faculty of Medicine, Departments of Anatomy, Edirne, Turkey.

**** Trakya University Faculty of Medicine, Departments of Pathology, Edirne, Turkey. 
granules lose their electron density, or that the contents become disarranged, just before the granule limiting membrane fuses with the cell limiting membrane, resulting in release of the granular material, during the second type secretion. The second type of renin release they proposed was diacrine secretion. They reported that diacrine secretion was not morphologically detectable.

To date, there is still limited in vivo morphologic study for the exocytotic release of granules, or for the existence of other secretory mechanisms in juxtaglomerular cells. The complicated process of exocytosis, which involves fusion of two different membranes, is extremely difficult to visualize. Some researchers postulate that exocytotic renin release occurs too rapidly to see or other processes such as diacrine secretion happens in these cells, so that it is almost impossible to visualise the secretion of renin.

The aim of this study was to investigate the secretory mechanism(s) of the granules in juxtaglomerular cells at ultrastructural level. A detailed examination of the fine structural features of the granules in juxtaglomerular cells of adult rat kidneys was made by using electron microscopy.

\section{MATERIAL AND METHOD}

Twelve female Sprague-Dawley rats had daily intraperitoneal injections of CyclosporinA. All experiments were done in the laboratory of Trakya University, in accord with the criteria of the Ethics Committee at the University. The tissue specimens had been fixed by immersion in $3 \%$ glutaraldehyde, and then postfixed in $1 \% \mathrm{OsO}_{4}$. After this, they were washed in either phosphate or cacodylate buffer, dehydrated in a graded ethanol series, and finally washed in propylene oxide. Next, the samples were embedded in Araldite. Semi-thin sections 0.6-1 mm thick were cut on an Ultracut-E microtome and stained with toluidine blue.

The juxtaglomerular apparatuses of the glomeruli present in the blocks were first located in these semi-thin sections under light microscopy. Juxtaglomerular cells were identified by their location and their granules. Whenever possible, the blocks were oriented so as to be sectioned in a direction either perpendicular to or parallel to the long axes of the afferent arterioles. All of the juxtaglomerular cells thus located were cut in serial sections. Thin sections were cut with diamond knives on the same microtome, and were mounted on either nickel or copper grids. They were then stained with uranyl acetate and lead citrate. Zeiss EM9 and Jeol 100 CX electron microscopes were used to examine the sections, and photographs were taken of regions of interest.

\section{RESULTS}

Juxtaglomerular cells typically exhibit variable rather than uniform structural patterns with respect to nuclear characteristics, amount of cytoplasm, occurrence and extent of cytoplasmic granules (Figs. 1a-b-c, 2). In the specimens we studied, the juxtaglomerular cells were either located between the macula densa and the vessel wall (Fig. 1a, 1b, Fig. 2), or were clustered around the arteriolar wall (Fig. 1c). Some cells were very close to the macula densa (Fig. $1 \mathrm{a}-\mathrm{b}-\mathrm{c}, 2)$, while at other sites there was interstitial tissue between the cells and the macula densa (Fig.1a-b).

The structural characteristics of the granules differed somewhat from one cell to another as seen in all fiures. In general, the granules were less or more osmiophilic, often irregularly shaped. Each was surrounded by a single smoothsurfaced membrane. They were scattered throughout the cytoplasm of the juxtaglomerular cells, and the numbers and sizes of granules in each cell varied greatly.

A few cells showed clear sites of fusion between granule membrane and cell membrane (Figs. 3, 4). Extrusion of granule contents outside the juxtaglomerular cells was also occasionally seen (Fig. 3). A number of cells showed many invaginations of the cell membrane, and we noted fusion of the cell and granule membranes when granules were close to these invaginations (Figs. 3, 4, 5).

Another interesting feature we observed was structural disorganization in some granules located in the peripheral cytoplasm (Figs. 5, 6). These granules showed variable degrees of rarefaction and loss of limiting membrane. It seemed that their contents had diffused into the surrounding cytoplasm, and was then transported to the interstitial tissue (Figs. 5, 6). Teher were also some granules in these cells which fused demonstrated fusion between the granule membranes and the cell membranes.

We observed no free granules in the extracellular spaces that were similar to juxtaglomerular cell granules.

\section{DISCUSSION}

As outlined above, our main purpose in this study was to characterize the fine structural features of the secretory mechanisms of juxtaglomerular cell granules at morphologic level. The study presents electron microscopic evidences about the secretion from juxtaglomerular cells for the first time. 

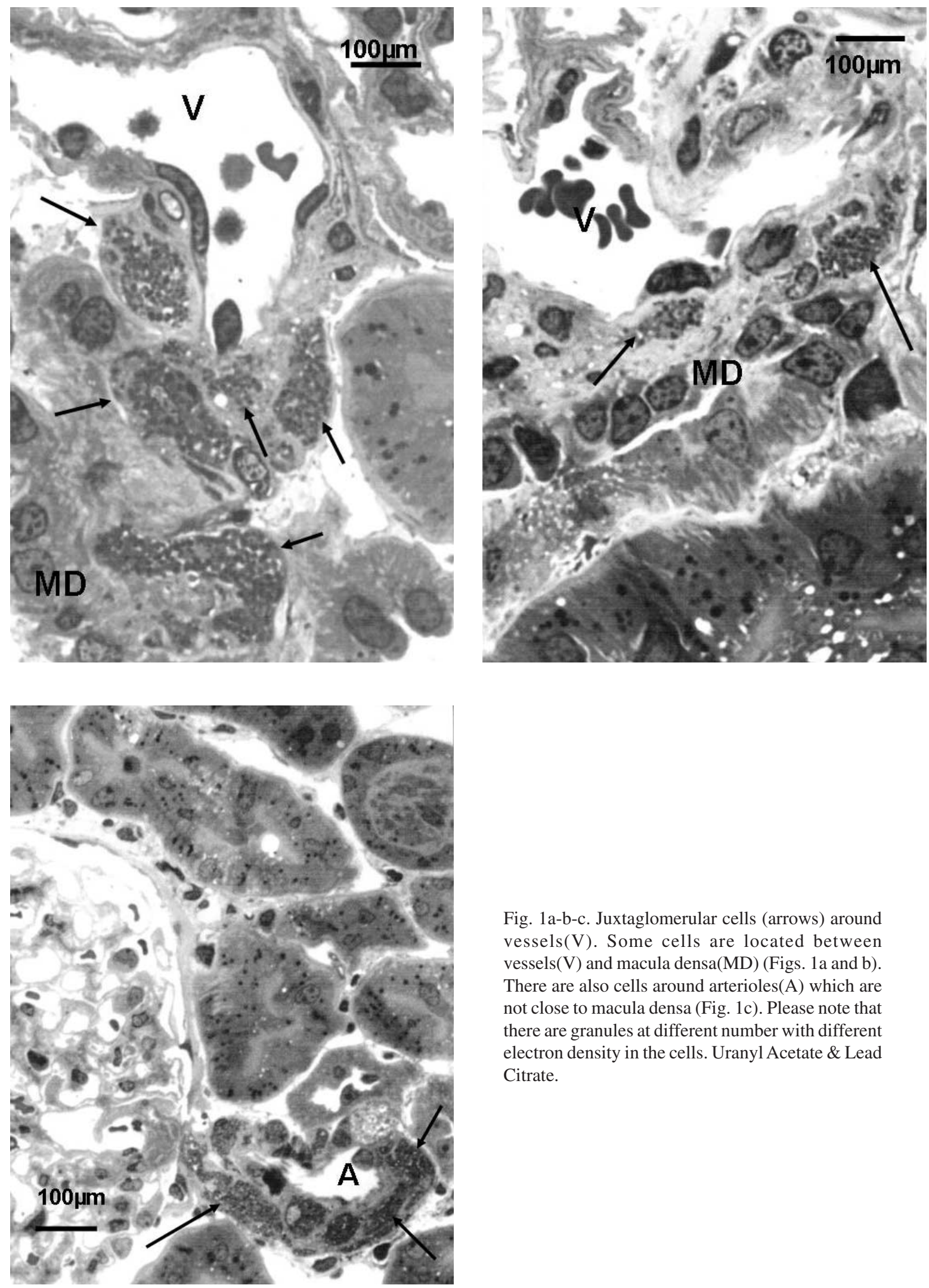

Fig. 1a-b-c. Juxtaglomerular cells (arrows) around vessels(V). Some cells are located between vessels(V) and macula densa(MD) (Figs. 1a and b). There are also cells around arterioles(A) which are not close to macula densa (Fig. 1c). Please note that there are granules at different number with different electron density in the cells. Uranyl Acetate \& Lead Citrate. 


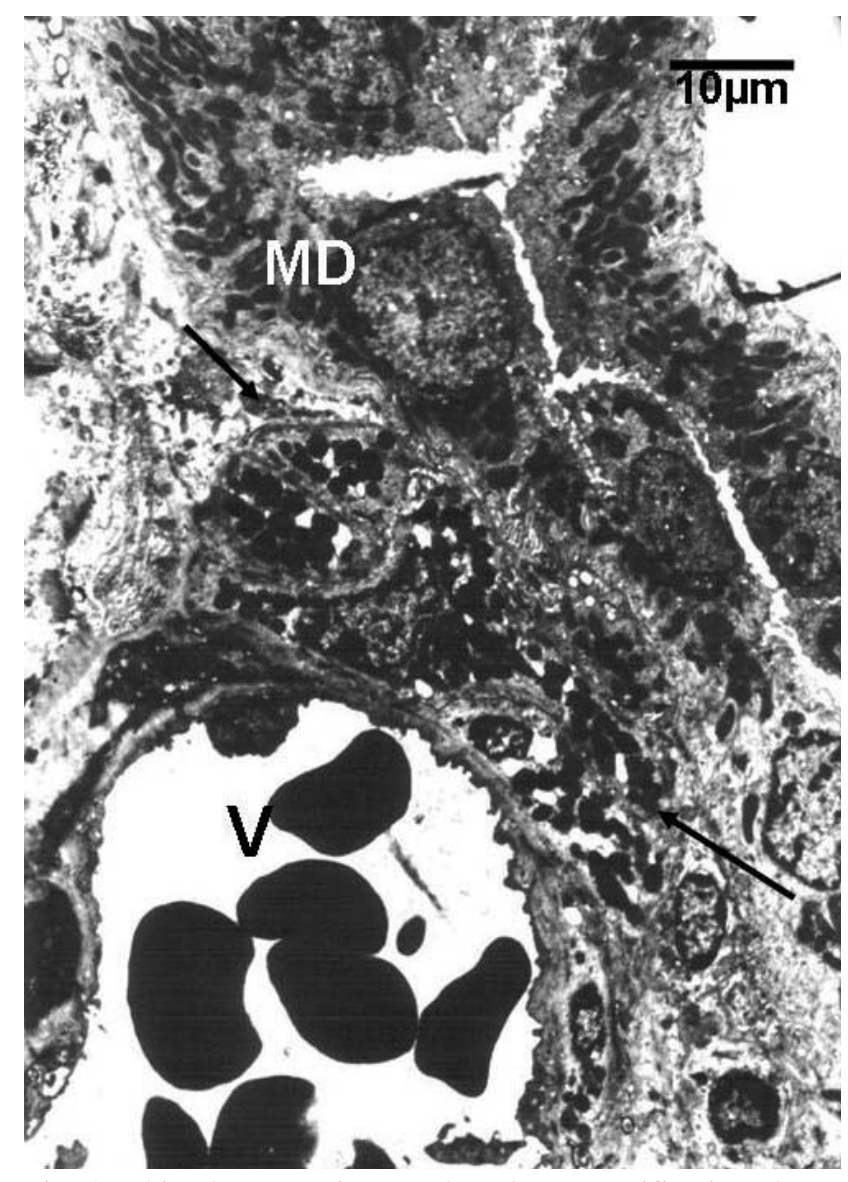

Fig. 2. This electron micrograph at low magnification shows juxtaglomerular cells (JGC) clustered in close proximity to the arteriolar wall. They are located between vessel(V) and macula densa(MD). Uranyl Acetate \& Lead Citrate.

We observed actual fusion between the plasma membrane and the limiting membrane of some granules, and also noted extrusion of granule contents into the extracellular matrix. These findings suggest that exocytosis is one of the secretory mechanisms in vivo. This is consistent with the findings of some previous investigations (Berka et al., 1990; Kon et al.; Berka et al., 1993). Wassenberg \& Martin (2002) also did an immunohistochemical study which supports the exocytotic process in these cells. They found a protein in juxtaglomerular cells like some other endocrine cells: Calciumdependent activator protein for secretion (CAPS 1). This protein is important for the regulation of calcium-triggered dense-core vesicle exocytosis. Peti-Peterdi et al. (2004) provided direct visualization of renin degranulation in vitro in a recent study. They reported that the fast dimming and disappearance of quinacrine-labeled renin granules, the emptying of granule content, and the extracellular quinacrine cloud or flash were all classic signs of exocytosis, the main mechanism for renin release, as suggested by many investigators. They found no indication of granule shrinkage or increasing quinacrine

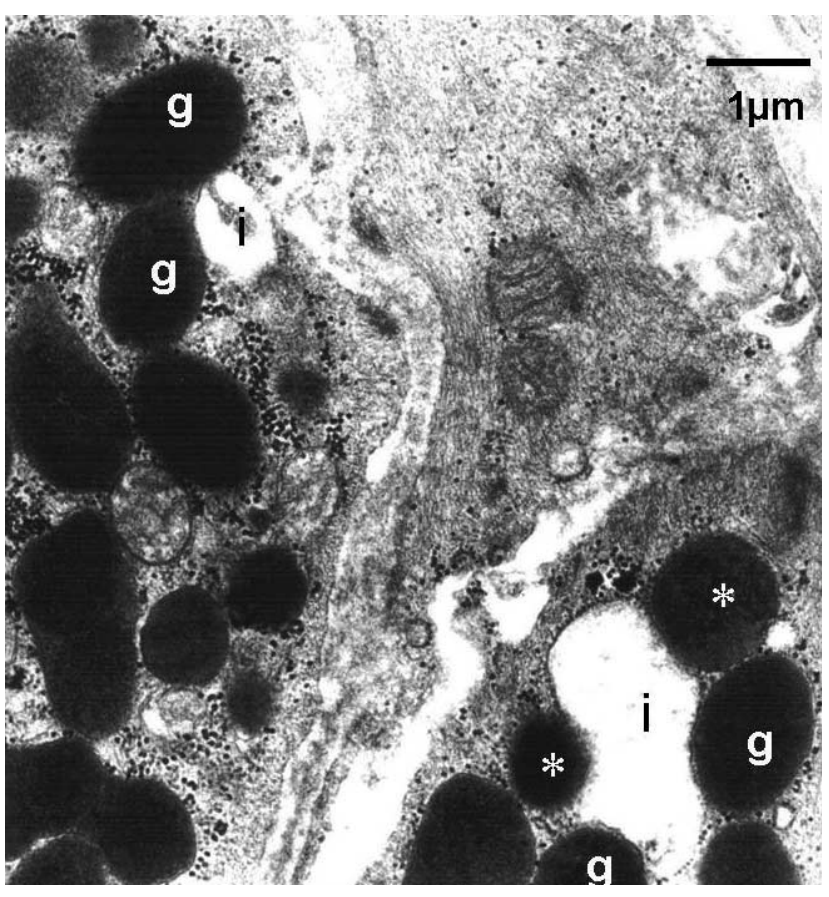

Fig. 3. Fusion sites between granules(g) and cell membranes are clear around the invaginations(i) of juxtaglomerular cell membranes. Extrusion of granule contents outside the juxtaglomerular cells into the invaginations was also occasionally $\operatorname{seen}(*)$. Uranyl Acetate \& Lead Citrate.

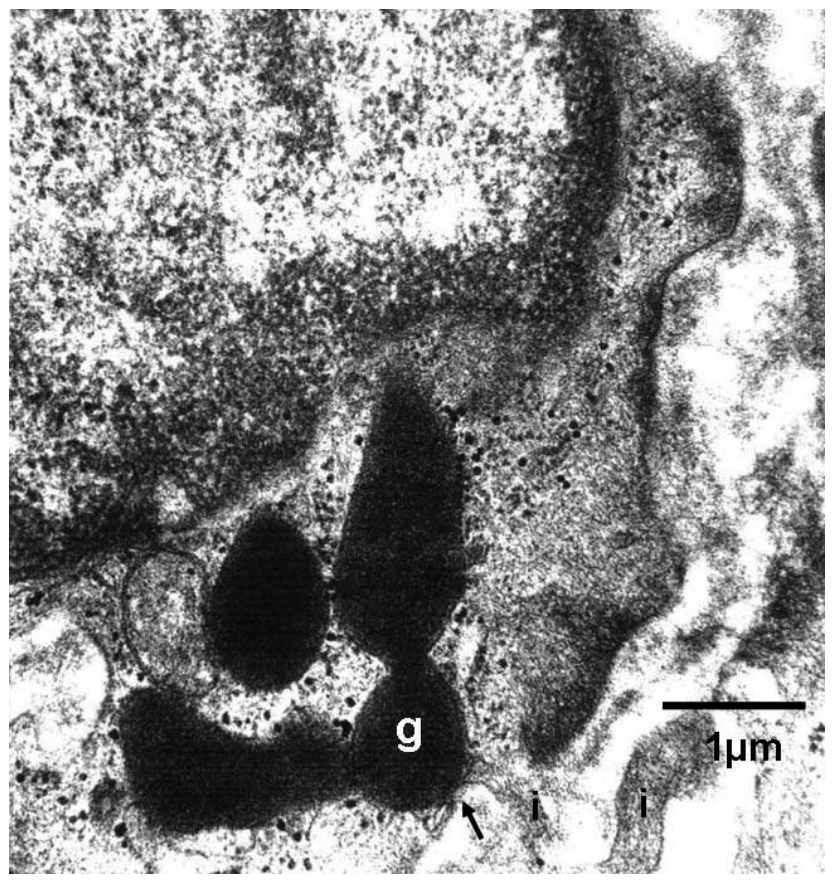

Fig. 4. This image shows fusion(arrow) between the granule (g) and the cell membrane which is close to the invagination site. Uranyl Acetate \& Lead Citrate.

fluorescence in the cytosol, which argues against the cytosolic solubilization theory of renin release. 

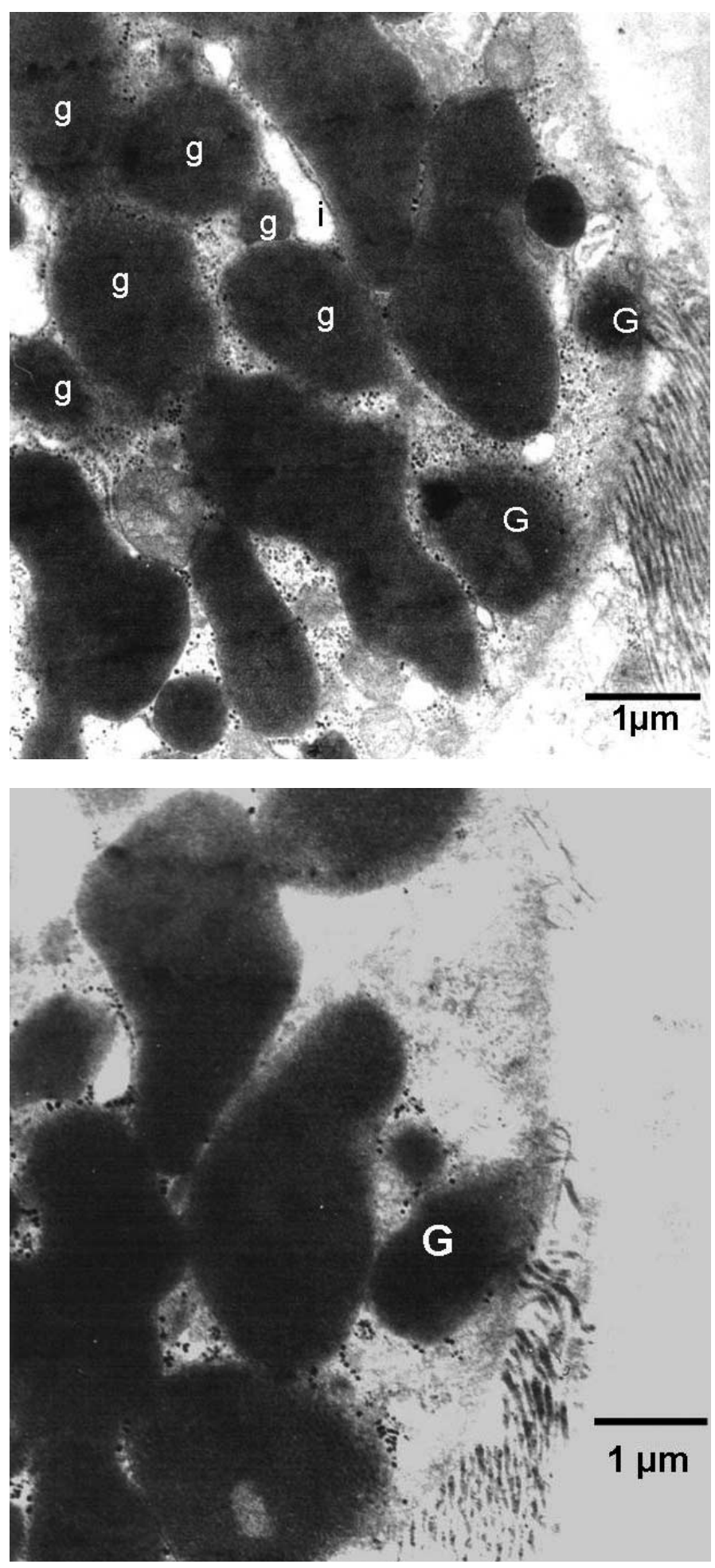

Figs. 5 and 6. There are three granules (G) in different two juxtaglomerular cells which appears that contents are being discharged into the cytosol. This material is then presumably transported into the intercellular space. Invagination (i) and sites of fusion between the granules ( $\mathrm{g}$ ) and cell membranes are also evident in the same cells. Uranyl Acetate \& Lead Citrate.
However, Kon et al. outlined morphological characteristics of this exocytotic process that are somewhat different from what is seen in other cells. The ultrastructural features of some of the secretory granules they observed indicate that a process similar to what occurs in other endocrine cells may also take place in juxtaglomerular cells.

We noted exocytotic granules in close proximity or fused to the cell membrane at invagination sites. Our images also revealed that exocytotic granules are mainly localized at the periphery of the juxtaglomerular cells. This might be significant evidence for the theory that renin is secreted mainly into the interstitium of the kidney, not into the vessel lumen (Lindop \& Lever, 1986; Kon, 1999).

Another interesting finding in only two juxtaglomerular cells was discharge of granular materials into the cytosol (Figs. 6, 7). The most likely next step after this would be some mode of transport into the intercellular space. We interpreted this finding as diacrine secretion. This morphologic evidence suggests that diacrine secretion might be the other secretory mechanism in juxtaglomerular cells. Diacrine secretion, which is also termed "transmembrane effusion," is very difficult to detect morphologically. The ultrastructural findings in this study might be a microscopic evidence of this type of secretion for the first time and support the above-mentioned hypothesis of Kon et al.

Interestingly, we also observed that these juxtaglomerular cells exhibited two different types of secretion in the same cell. There were fusion of the membranes of secretory granules and cell membranes while we also observed the discharge of granular material into the cytosol. (Fig. 5). This indicates that exocytosis and diacrine secretion might occur simultaneously in the same cell.

In conclusion, this is the first in vivo electron microscopic study which presents morphologic evidences for two distinct secretory mechanisms for renin release; namely, exocytosis and diacrine secretion. We propose that diacrine secretion also might occur in some cells even with the exocytotic process. Our observations in many juxtaglomerular cells shows that it is extremely difficult to visualise exocyotic granules or diacrine secretion in these cells. Because of that; it is almost impossible to be able to make statistical analysis about these two type secretions. Further studies will answer the questions about when and how a juxtaglomerular cell promotes the use of one of these secretion mechanisms. 
AKTAS, R. G.; KARABAY, G.; TASKINALP, O. \& KUTLU, A. K. Evaluación con microscopía electrónica de los mecanismos secretorios de renina desde las células juxtaglomerulares. Int. J. Morphol., 28(3):723-728, 2010.

RESUMEN: Aunque la estructura y las funciones de las células yuxtaglomerulares (JG) han sido bien definidas, todavía existe controversia acerca de los mecanismos de secreción de renina en estas células. Se ha supuesto, en muchos estudios, que la exocitosis es el principal mecanismo de secreción de estas células, mientras que otros autores sugieren que la secreción se produce de una manera muy diferente en estas células. Hay varios estudios que plantean que la secreción diacrina, que es muy difícil de visualizar, podría ser otro mecanismo para la secreción de renina. Este estudio tiene como objetivo encontrar las respuestas a estas interrogantes mediante la identificación de las características estructurales de la secreción de gránulos en las células yuxtaglomerulares. Ciclosporina A (CyA) se ha utilizado en el estudio experimental actual, debido a que se ha informado que este medicamento aumenta el número de células JG y estimula la secreción de renina. Doce ratas hembras Sprague-Dawley fueron diariamente inyectadas por vía intraperitoneal, con CyA durante diez semanas. Las muestras de tejido renal de estos animales fueron examinadas a través de microscopía electrónica. Detalladas características estructurales han sido examinadas en los gránulos secretores de las células yuxtaglomerulares. Se ha observado una cantidad considerable de gránulos, que va con el proceso de exocitosis. Además, se encontaron células que habían secretado el contenido de sus gránulos de manera diferente. Esto fue interpretado como secreción de tipo diacrina. En conclusión, este estudio in vivo presenta evidencias morfológicas que demuestran que tanto la exocitosis y la secreción diacrina podría ocurrir en células JG. También tuvimos la oportunidad de observar probables gránulos secretores, que mostrarían "la secreción diacrina", que es muy difícil de visualizar, a nivel de microscopía electrónica. Este informe también proporciona la prueba morfológica que demuestra que estos dos mecanismos distintos de secreción podrían realizarse simultáneamente en las mismas células yuxtaglomerulares.

PALABRAS CLAVE: Células juxtaglomerulares; Gránulos de secreción; Microscopía.

\section{REFERENCES}

Berka, J. L.; Alcorn, D.; Coghlan, J. P.; Fernley, R. T.; Morgan, T. O.; Ryan, G. B.; Skinner, S. L. \& Weaver, D. A. Granular juxtaglomerular cells and prorenin synthesis in mice treated with enalapril. J. Hypertens., 8(3):229-38, 1990.

Berka, J. L.; Alcorn, D.; Ryan, G. B.; Skinner, S. L. \& Weaver, D. A. Renin processing in cultured juxtaglomerular cells of the hydronephrotic mouse kidney. J. Histochem. Cytochem., 41(3):365-73, 1993.

Fray, J. C.; Lush, D. J. \& Valentine, A. N. Cellular mechanisms of renin secretion. Fed. Proc., 42(15):3150-4, 1983.

Friis, U. G.; Jensen, B. L.; Hansen, P. B.; Andreasen, D. \& Skøtt, O. Exocytosis and endocytosis in juxtaglomerular cells. Acta Physiol. Scand., 168(1):95-9, 2000.

Friis, U. G.; Jensen, B. L.; Sethi, S.; Andreasen, D.; Hansen, P. B. \& Skøtt, O. Control of renin secretion from rat juxtaglomerular cells by cAMP-specific phosphodiesterases. Circ. Res., 90:996-1003, 2002.

Friis, U. G.; Stubbe, J.; Uhrenholt, T. R.; Svenningsen, P.; Nüsing, R. M,; Skøtt, O. \& Jensen, B. L. Prostaglandin E2 EP2 and EP4 receptor activation mediates cAMP-dependent hyperpolarization and exocytosis of renin in juxtaglomerular cells. Am. J. Physiol. Renal. Physiol., 289(5):F989-97, 2005.

Kon, Y. Comparative study of renin-containing cells. Histological approaches. J. Vet. Med. Sci., 61(10):1075-86, 1999.

Kon, Y.; Hashimoto, Y.; Murakami, K. \& Sugimura, M. An immunoelectron-microscopical observation of mouse juxtaglomerular cells in the case of experimental hydronephrosis. Acta Anat., 144(4):354-62, 1992.
Lindop, G. B. \& Lever, A. F. Anatomy of the renin-angiotensin system in the normal and pathological kidney. Histopathology, 10(4):33562, 1986.

Ogawa, K.; Yamasato, M. \& Taniguchi, K. Exocytosis of secretory granules in the juxtaglomerular granular cells of kidneys. Anat. Rec., 243(3):336-46, 1995.

Persson, A. E.; Ollerstam, A.; Liu, R. \& Brown, R. Mechanisms for macula densa cell release of renin. Acta Physiol. Scand., 181(4):471-4, 2004.

Peti-Peterdi, J.; Fintha, A.; Fuson, A. L.; Tousson, A. \& Chow, R. H. Real-time imaging of renin release in vitro. Am. J. Physiol. Renal Physiol., 287:F329-35, 2004.

Rasch, R.; Jensen, B. L.; Nyengaard, J. R. \& Skøtt, O. Quantitative changes in rat renin secretory granules after acute and chronic stimulation of the renin system. Cell Tissue Res., 292(3):563-71, 1998.

Schweda, F. \& Kurtz, A. Cellular mechanism of renin release. Acta Physiol. Scand., 181(4):383-90, 2004.

Skøtt, O. Episodic release of Renin from single isolated superfused rat afferent arterioles. Pflugers Arch., 407: 41-5, 1986.

Wassenberg, J. J. \& Martin, T. F. Role of CAPS in dense-core vesicle exocytosis. Ann. N. Y. Acad. Sci., 971:201-9, 2002.

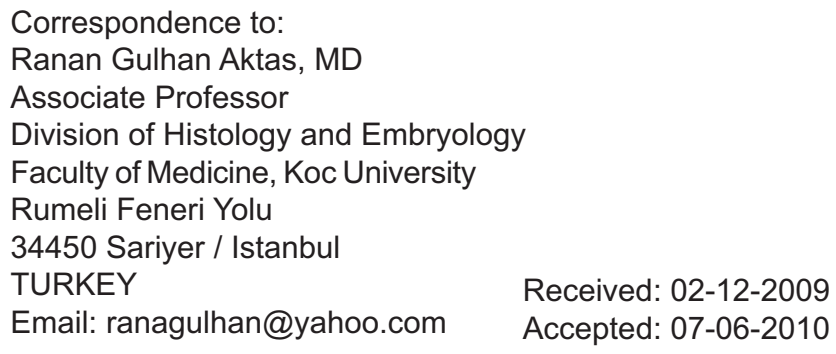

Received: 02-12-2009

Accepted: 07-06-2010 